\title{
The Existence Of Bagang Rambo In Gulf Of Bone (The Case Study Of Fisherman Community In Tarasu Village)

\author{
$1^{\text {st }}$ Amirullah \\ Faculty of Social Science \\ Universitas Negeri Makassar \\ Makassar, Indonesia \\ Amirullah8505@unm.ac.id
}

\author{
Faculty of Social Science \\ Universitas Negeri Makassar \\ Makassar, Indonesia \\ Saleh.madjid@unm.ac.id
} \\ $2^{\text {nd }}$ Saleh Madjid

\author{
$3^{\text {rd }}$ St. Junaeda \\ Departemen of Antropology Education \\ Faculty of Social Science \\ Universitas Negeri Makassar \\ Makassar,Indonesia \\ st_junaeda@unm.ac.id
}

\begin{abstract}
This paper or study aims to determine the life of the Bagang Rambo chart fishermen in the village of bone bay in Tarasu village in and understand the socio-economic life and profit-sharing system. This research is descriptive analysis using historical method, comprehensive; heusristic, criticism of interpretation and histriography. The result of research shows that there are several factors that influence the emergence of rambo fishers in the coastal bay of Bone Tarasu Village, namely because of heredity / inheritance, geographical and character of the population and is a coastal area of bone bay and the average community Tarasu village profession as a fisherman, as for the main fishing gear that became the basic fishing equipment used by Tarasu Village fisherman Bagang Rambo, where in the traditional era of fishermen using bagang tancap while in the modern era using Bagang Rambo, The socio-economic life of Bagang Rambo's fishermen has increased, along with the technological advances of fishing gear and the use of motorisation of Rambo's boats, even already developed and improved for the children of fishermen, both the owners of capital and fishermen mustard. In addition, there is also a change in the pattern of life of the fishing community of Bagang Rambo
\end{abstract} Bone.

Keywords - fishing community of Bagang Rambo, Gulf of

\section{INTRODUCTION}

Indonesia's population growth is quite high every year, and the availability of land or land on land that is increasingly depleted land even narrower, the marine sector, especially fishing effort become an alternative and strategic for the community to stay in the fulfillment of everyday life and the future for fishermen

South Sulawesi, including the territory of Indonesia which has the potential of sea and coastal areas. This potential is utilized by most people to make fishing business as one source of income, both as a major livelihood, and as a side of other livelihoods.[1], [2] One of these coastal potentials is the existence of Bone Bay as an area and sentera fishing industry by fishing communities.

This study is a maritime history study, specifically reviewing everything related to the development of marine activities, in general maritime history covers all aspects of the extent of human activity related to marine /maritime. [3]

It is similar researcher in the fishing community of Bagang Rambo hawk that operates on the coast of Bone Bay
Tarasu Village, that people cultivate fishermen bagang Rambo. In Tarasu Village various professions exist such as; Civil servants, rice businessmen, farmers, voyagers and fishermen. Fisherman Profession at Tarasu Village very varied, there are fisherman tuna, brackish fisherman, fisherman Bagang Rambo. In this study the authors are just trying to describe the profession of Bagang Rambo fishers with cluster / level according to the division of labor that is there are large fishermen owners of capital, small fisherman / owner Bagang Rambo and laborer fisherman (Sawi).

Assessing the fishing community of Bagang Rambo in Tarasu village is interesting to be studied, how is the development, the socio-economic changes of owners of capital (Punggawa) and the mustard and the impact of the existence of Rambo fishermen amid modern technological advances.

\section{RESEARCH METHODS}

The stages of the methods undertaken in this study is by the method of historical approach with descriptive analysis and analysis with the steps as follows: Heuristics is an early stage directed at exploratory activities, search and collection of sources related to the problem under study. Source criticism; is the filtering of field data and supporting data as reading material, articles, to obtain objective facts. Next step Interpretation; the process of analyzing data that has been criticized can be called a historical fact. But that fact will be interpreted as objectively as possible by not abandoning the scientific nature. The last stage is Historiography; namely the process of presentation, the writing of history and convey the synthesis obtained in the form of the story of history, this is the last step presents data and facts that have been formulated and analyzed into the form presentation of a whole and interesting.

\section{RESULTS AND DISCUSSION}

\section{A. Existence and Development of Bagang Rambo Fishermen in Tarasu Village}

Related to the philosophy in the system of government, Fisherman is defined as a person whose eyes seek from fishing effort at sea.[4] Therefore, fishing communities can be interpreted as people or people who live together in the old ralative time, who are aware that they are a unity and 
have a job or livelihood of catching fish and other marine products.

Tarasu village is a village located in Kajuara Sub-district of Bone Regency and some residents work as fishermen, Rambo's fishing history in Tarasu Village according to interview information of the researcher to $\mathrm{H}$. Burhanuddin, that the beginning of knowing Bagang Rambo in Tarasu village was introduced by the family has been hereditary in the profession of fishermen since the 1970s at the time was still using a small boat and jarring size $10 \mathrm{~m} 2$ and widely known to the public by the name Bagang Dua. In its development then known as Bagang Rambo after being introduced by $H$. Daeng Mallongi who is domiciled in Angkue Village which already has bagang modern Rambo in 1980 and has been operating in the coastal area of Bone bay.

Further information from the local community obtained data that the fisherman Bagar Rambo in Tarasu is known as Bagang Tancap and Bagang Dua in the 1960-1970s and at that time still traditional, after the introduction of modernization of fishing gear (machine) in 1980s on bagang two, and after the introduction of Bagang Rambo a little larger than Bagang Dua, then gradually community in Tarasu choose to be a fisherman Bagang Rambo that has been introduced by fisherman H. Daeng Mallongi.

Bagang Rambo, is a more modern fishing gear and has been using a large technology tool and the use of jarring machine fluorescent lights / flare which has 500 watts of power, and has a small boat (Jolloro) as a means of transportation of the men (sawi) to descend to Bagang Rambo.

According to $\mathrm{H}$. Burhanuddin that Bagang Rambo is a kind of floating boat that has a jarring as a means to catch fish such as fish tembang, small fish / anchovy and fish katombong.

The existence of Bagang Rambo in the village of Tarasu encourages the local community's economy to encourage some Tarasu villagers to pursue a profession as a fisherman, either as a fisherman, as a fisherman, as a fisherman, as a fisherman (sawi), in addition to meeting the daily needs of the laborers (sawi) fisherman's children are mainly fishermen capital owners (Punggawa) even for home investment in the city.

\section{B. Motorization Process and Fishing Activity}

Fishing business in South Sulawesi has many uses modern tools, characterized by motorization of boats and the use of types of fishing gear that is sophisticated but still there are using traditional fishing gear because of inability in terms of capital so that the catch of fishermen are still traditional only for the fulfillment day-to-day, even sometimes the income of modern fishermen is usually uncertain. [5]-[7]

The business of motorization and machining of fishing mechanisms in Indonesia generally began to be applied since the 1970s. Even further the existence of the development efforts of fisheries and Fish Auction Places (TPI), which directly grow the fishermen's economy. This is in line with the results of the interview with H. Daeng Majeppu that since the presence of Lappa TPI in Sinjai equipped with facilities supporting meiputi clean water, ice beams, boat workshop machine can increase production power and increase the level of fisherman economy because the fish catch can be sold directly and not again quickly rotted because there is already ice beams .

The fishing area not far from the coast is only 3 (three) to 5 (five) miles from the beach and the catch is usually 2-3 hours boat trip that carries the catch fish for sale TPI Sinjai. The owner of Bagang fisherman sells the catch to the owner of capital or punggawa who has lent the capital for purchasing Bagang Rambo, so the fish catch must be sold to the great Punggawa. According to Daeng Patappe that our catch fish direct us down to TPI Lappa Sinjai for sale by Punggawa (Owner of capital) and the proceeds will be calculated at the time of profit sharing for one month

Efforts to improve fishing technology become a must in efforts to maximize the potential of fisheries. Not only the boat that developed in Tarasu Village but bagang which became the main tool of Tarasu Village fishermen also experienced the impact of moderation, such as the use of boat outboard engine, Rambo bagel light machine. And the use of a rotary machine to increase the jarring of fish.

Bagang Rambo, which operates in Bone Bay, has been improving since the 2000s since this bagang itself has been using modern tools so easy to simplify the fishermen in the process of catching their own fish and according to the informant $\mathrm{H}$. Buthanuddin that the price of 1 unit Bagang Rambo around 700 million - 1 billion.

The fishing activities of the Bagang Rambo fishermen are very unique and different from the traditional ways of fishing, the bagang (sawi) fishermen begin to prepare the tools or equipment needed when going to the sea, such as preparing boats (jolloro), checking boat engines and carry a fish or basket cork that is usually filled with ice cubes that have been destroyed at the location where the boats of the fishermen parked or stored beside the river which is usually called the local community is Port TujuTuju, but the ice is brought only when the next day will bring the fish or harvest time is to be done in the evening.

Fishermen activity down the sea is done in the afternoon at 05.00 and the fishing gap time to the fishing location about 2-3 hours even if the location is quite far usually the time required is usually 4 hours.

\section{Profit Sharing System Owner and Owner Bagang (Juragan) with workers (Sawi)}

Profit sharing system among fishermen community, in principle is an assessment of the factors of production used in fishing business. Elements of the factors of production referred to in this context are capital owners, oprasioanal costs, punggawa (Owners of boats or leaders of fishing activities), workers (sawi).[6] The calculated component in profit sharing system in fishing community in Tarasu Village is the owner of capital, operational cost, tools (Boat / machine) and labor (punggawa / sawi).

Fishermen who own bagang in Tarasu Village do the fish search process using their own fishing gear but given the capital by big skipper / owner of capital so that the owners / owners of bagang have obligation to share or deposit their catch that is $20 \%$ to the owner of capital as a form of cutting the proceeds of capital lending and $10 \%$ for bagang owners 
and $50 \%$ for operational costs, baggage repair and fishing machines and equipment if any damaged, then $20 \%$ for the distribution of skipper and worker (sawi).

The unique thing in revenue sharing in the fishing community of Rambo in the village of Tarasu is the CK system (looking for friends) the term in Bugis is the mustard (Sawi), commonly taken by the mustard who want to ride home with the merchant, because in general work system that has been patterned in the fishing community Rambo bagang Tarasu Village is change each other (mustard gleaming up and down to bagang). If the number of workers (sawi) is 14 people then they alternate up and down the merchant, that is 7 people just waiting for the trade and 7 other people take the fish escort to the auction with the merchant, where 7 people are raising that get the $\mathrm{CK}$ (Akkanreangen sawi) to eat at home.

The mustard bagang Rambo generally feel happy if their catch is abundant because in addition to the salary wages are also high also CK results in get also increased. This is in line with the results of interviews to Taming (one of the mustard gowns), that if the catch of fish is found, the cockwere change each other rise to gather with the family also get the CK result also increases, because usually the CK is sold in the fish auction (TPI). The result of the sale of mustard (sawi) over CK obtained is an additional wage of salary excluding the salary of 1 month or 3 month salary result per payroll by the owner of Rambo bagel.

The wives of fishermen generally do not have a job that can help increase family income. These wives are more preoccupied with their domestic roles as housewives because they do not have or lack special skills that can be used to supplement their husband's income as mustard fishermen

However, not a few fishermen's wives contribute to the work of their husbands to market the catches their husbands get as a result of CK (search for friends) as a result of giving fish catches if they are abundant or if the catch exceeds 5 (five) baskets (baka) then mustard $\mathrm{CK}$ was given a quota to be divided into 1 basket for mustard greens which would take the fish to land (TPI Lappa Sinjai). And sometimes the CK results are sold directly by mustard fishermen in TPI, some are even directly dropped back home to be eaten and sold with neighbors and this is usually done as a social form to neighbors not selling expensive $\mathrm{CK}$ products such as the price of fish in the market but selling it with cheap prices and usually the sale of fish is done by the wife of a mustard fisherman

Bagang Rambo sharing system is usually erratic every month but the payroll system is usually dependent also from the catch, and the salary in the fishermen bagang (mustard) is uncertain sometimes they get a monthly wage if the operation bagang at sea was smooth and there are no constraints on the jarring, bagel engines and regular salary wages are given 2-3 months in the operation of their new sea payday, usually wages or salaries earned members of the workers (mustard) every 2 million ordinary people reach 4 million outside of the results $\mathrm{CK}$

\section{The relationship between retainer and mustard fisherman Bagang Rambo}

In the outline, fishing and collecting marine products in the fishing community of Tarasu Village, generally divided into two, the first is done in groups, the second is done individually. However, both forms of fishing and collecting marine products continue to use the same system, namely the patron-client system or known locally as Punggawa-Sawi, in the local Bugis language called 'Punggaha-Sahi'. Punggawa (Punggaha) is the owner of capital, such as money, fishing gear, ships, machinery. Whereas Sawi (sahi) or commonly known as labor fishermen are the working class or fishermen who carry out fishing and collecting marine products both independently and in groups.

In Tarasu Village community, bagang Rambo fishermen are formed by two patterns of understanding of Actors, namely as a large Punggawa (capital owner) and a small retainer, a bagang owner and commonly referred to as a Trader. The concept of the actor as a Great Courtier who has business capital to lend to a small retainer / juragang, this relationship is formed as a business capital for the purchase of Bagang Rambo for juragang with the form of catching exchanges being a means of payment of the capital proceeds provided by the big retainer. And this is the beginning of the attachment of a Patron-Client relationship between a big retainer and a small retainer.

Relational Adherence is an economic action that is socially situated and attached (embedded) in the ongoing personal social network between the actors between the big retainer and the Small and Sawi Punggawa who are not only economically adjusted.

Physical insecurity and social conditions that also support the presence of patron client relationships are physical and social insecurity amid the scarcity of important commodities needed [9]. The best way for them is to stick to or rely on someone who is more powerful, who is better able to protect or give them everything that is needed. Likewise, the conditions experienced by Bagang Rambo fishermen in Tarasu Village. The atmosphere is not safe either physical or social will be felt when their arrival without the help of acquaintances, relatives, friends who are willing to give physical or social guarantees. Those who are willing to provide physical and social security are referred to as patrons. The physical and social security provided by the owner of the capital is a place to live, seek residence permits, provide employment, and guarantee daily life including mustard families who have married. In addition, patrons also provide health insurance to their workers. This is in line with what Taming said that "the mustard greens that usually suffer from their families, the juragang (Small Retainer) contributes / guarantees health for treatment". (interview, 12 March 2018).

The form of work relationship or work attachment between a large retainer and a small retainer / juragang, or an individual fisherman in a social relationship conducted by a fisherman's household, involves two individuals. It is also seen between the retainer and mustard greens and usually a retainer of ordinary capital owners also acts as a fish registrar and is responsible for the sale of catches under the small retainer or juragang, even the big retainer is responsible for all tools and equipment including all financial in every arrest 
operation including fulfillment of urgent needs rather than small retainer / flaws, this is in line with what was stated by $\mathrm{H}$. Burhanuddin that "the urgent needs by the small retainer / juragang usually they ask for help to the big retainer both the needs the good points of our family are limited and rational, such as if there is a small retainer who wants to marry off his son then the big retainer (capital owner) can provide assistance. (interview, May 13 2018).

The relationship between the Small Retainer and the Mustard does not only occur when going to sea but when on the ground Tarasu fishing communities are also seen when repairing the Bagang Rambo vessel, they work hand in hand with the small retainer (juragang) in repairing the damaged Rambo bagang structure. on the body of the boat for Rambo. Bagang Rambo repair is usually done when Bagang Rambo conditions or bagang boats experience kebocorang, jarring damaged / torn and Bagang Rimbang broken.

\section{CONCLUSION}

Tarasu villagers are familiar with fishing gear like rambo handbag since 1970s with the name of bamboo (bagang tancap) and developed into (bagang dua), and at that time it is not yet modern, The use of bagang Rambo as a means of fishing in the waters of the bay bone is done since the $1980 \mathrm{~s}$ along with the development of motorisation on boats (Jolloro) and development of Rambo bag in bone bay is very significant especially in the 2000s Rambo fishers in Tarasu Village more and more about 28 bagang Rambo. The socioeconomic life of the fishing communities of Rambo in the Tarasu village is on the rise, the community uses the means of producing the fishing well. Supported also by improving the welfare of mustard which in general already have a motor vehicle, able to send their children, especially on fishermen skipper / punggawa who already have a car vehicle, permanent home and able to send their children to college

\section{ACKNOWLEDGMENT}

Acknowledgments to all the parties helping authorizers in making the research, whether assistly directly or not, and thank you to all elements who have supported it.

\section{REFERENCES}

[1] M. Spiegelberg et al., "Unfolding livelihood aspects of the Water-Energy-Food Nexus in the Dampalit Watershed, Philippines," J. Hydrol. Reg. Stud., vol. 11, pp. 53-68, 2017.

[2] R. Deswandi, "Chapter 4 - A Case Study of Livelihood Strategies of Fishermen in Nagari Sungai Pisang, West Sumatra, Indonesia," R. Febriamansyah, Yonariza, R. Ullah, and G. P. B. T.-R. D. \& D. of N. R. M. in A. Shivakoti Volume 4, Eds. Elsevier, 2017, pp. 45-60.

[3] G. Exarchopoulos, P. Zhang, N. Pryce-Roberts, and M. Zhao, 'Seafarers' welfare: A critical review of the related legal issues under the Maritime Labour Convention 2006," Mar. Policy, vol. 93, pp. 62-70, 2018.

[4] L. P. Carswell, S. G. Speckman, and V. A. Gill, "Chapter 12 - Shellfish Fishery Conflicts and
Perceptions of Sea Otters in California and Alaska," S. E. Larson, J. L. Bodkin, and G. R. B. T.-S. O. C. VanBlaricom, Eds. Boston: Academic Press, 2015, pp. 333-368.

[5] K. A. Naish et al., "An Evaluation of the Effects of Conservation and Fishery Enhancement Hatcheries on Wild Populations of Salmon1," vol. 53, Academic Press, 2007, pp. 61-194.

[6] J. A. Gulland and J. E. Carroz, "Management of Fishery Resources**This paper was first published, under the same title, as Chapter IV in 'The State of Food and Agriculture 1967' (F.A.O., Rome, 1967). Some changes have been made from the original version, principally in order to make the presentation more suitable for a scientific audience. In so far as there are differences from the earlier publication, these represent the views of the authors and are not necessarily those of the F.A.O.," vol. 6, F. S. Russell and M. B. T.-A. in M. B. Yonge, Eds. Academic Press, 1969, pp. 1-71.

[7] S. Whitmee et al., "Safeguarding human health in the Anthropocene epoch: report of The Rockefeller Foundation-Lancet Commission on planetary health," Lancet, vol. 386, no. 10007, pp. 1973-2028, 2015. 